\title{
Response of Six Begonia Species to Fertilizer Concentration and Substrate pH
}

\author{
Ka Yeon Jeong ${ }^{1}$, Claudio C. Pasian ${ }^{*}$, , Margaret McMahon ${ }^{1}$ and David Tay ${ }^{2}$ \\ ${ }^{I}$ Department of Horticulture and Crop Science, The Ohio State University, Columbus, Ohio 43210-1086, USA \\ ${ }^{2}$ International Potato Center (CIP), Apartado 1558, Lima 12, Peru
}

\begin{abstract}
Begonia albopicta, B. cucullata var. cucullata, B. echinosepala var. elongatifolia, B. holtonis, B. foliosa var. miniata and $B$. 'Fuchsifoliosa' are conserved at the Ornamental Plant Germplasm Center (OPGC), in Columbus Ohio as a source of germplasm for breeders and researchers. No cultural information for these species is available. Our objective was to evaluate the response of the above mentioned species to different fertilizer concentrations and substrate $\mathrm{pH}$ levels. Rooted cuttings were transplanted into plastic containers using a soilless mix. One of five concentrations ranging from 20 to $600 \mathrm{mg} \cdot \mathrm{L}^{-1} \mathrm{~N}$ of $17-5-17$ water soluble fertilizer were applied in irrigation water for 12 weeks. We found significant responses to the fertilizer concentrations and differences among species on weekly measured substrate EC, shoot length, leaf area, dry weight, average number of inflorescences, and SPAD readings. Growth parameters and visual observations were used to determine optimal fertilizer concentration. High quality B. albopicta, B. cucullata var. cucullata, B. echinosepala var. elongatifolia, and $B$. holtonis plants were obtained with 200 to $300 \mathrm{mg} \cdot \mathrm{L}^{-1} \mathrm{~N}$. On the other hand, low fertilizer concentration was found to be better for $B$. foliosa var. miniata and B. 'Fuchsifoliosa' in order to avoid high salt stress causing plant death. Seven different $\mathrm{pH}$ ranges of the peat-based substrates were obtained by adding different rate of dolomitic hydrated lime ranging from 1.0 to $2.6 \mathrm{~kg} \cdot \mathrm{m}^{3} . \mathrm{pH}$ was monitored weekly and maintained accordingly by adding flowable lime or a diluted sulfuric acid solution. The inflorescence number and SPAD readings were significantly different among six species, but there was no significant effect of substrate $\mathrm{pH}$. Significant interaction between species and substrate $\mathrm{pH}$ was found in shoot length, leaf area, and dry weight. Substrate $\mathrm{pH}$ between 5.6 and 6.0 was found to be adequate for B. albopicta, B. echinosepala var. elongatifolia and B. holtonis. B. foliosa var. miniata plant mortality was observed when grown at a substrate $\mathrm{pH}$ below 5.2. The information presented in this work will be useful to OPGC personnel in the maintenance of these species at their facilities, as well as to begonia breeders and collectors.
\end{abstract}

Keywords: Germplasm conservation, substrate fertility, substrate electrical conductivity, Begonia species, Begonia cultural practices.

\section{INTRODUCTION}

The Ornamental Plants Germplasm Center (OPGC, Columbus, Ohio) has been conserving begonia species and interspecific hybrids as one of the priority genera. The quality of the preserved plants is important to produce seeds and provide germplasm material for breeders and researchers. However, lack of specific cultural information may result in difficulties in maintaining the quality of theses begonia plants. Since all begonia plants at the OPGC greenhouses are grown in peat-based soilless substrates, cultural recommendations to determine optimal fertilizer concentration and substrate $\mathrm{pH}$ levels are required to enhance the research with and utilization of these species.

Monitoring substrate electrical conductivity (EC) and $\mathrm{pH}$ levels is recommended for greenhouse growers to timely and effectively manage fertilization $[1,2]$. Most soluble salts in the root-zone are derived from fertilization; thus, substrate EC, indicating the amount of soluble salts $[1,3]$, enables growers to determine the relative nutrient status in subs-

*Address correspondence to this author at the Department of Horticulture and Crop Science, The Ohio State University, 2001 Fyffe Ct. Columbus, Ohio 43210-1086, USA; Tel: 614-292-9941; Fax: 614-292-3505; E-mail: pasian.1@osu.edu trates. Substrate $\mathrm{pH}$ directly affects the availability of nutrients, such as calcium and magnesium as well as most micronutrients $[1,4]$. With the development of the PourThrough extraction method [3], frequent and efficient testing of substrate $\mathrm{EC}$ and $\mathrm{pH}$ in container-grown ornamental crops has become easier. [1] recommends that for floricultural crops, substrate testing every two weeks is necessary to detect trends in soluble salts and substrate $\mathrm{pH}$. Optimal substrate $\mathrm{EC}$ and $\mathrm{pH}$ for growing begonias in soilless media have been suggested: substrate Pour-Thru EC ranging from 1.0 to $2.6 \mathrm{mS} \cdot \mathrm{cm}^{-1}[5]$ and substrate $\mathrm{pH}$ ranging from 5.7 to 6.3 [6], respectively. However, these substrate $\mathrm{EC}$ and $\mathrm{pH}$ ranges may not be best for all of the over 1500 begonia species and thousands of hybrids. In addition, there is no study characterizing begonia species based on their response to different fertilizer concentrations and substrate $\mathrm{pH}$ levels.

Begonia albopicta W. Bull (accession number: OPGC 431), B. cucullata Wild var. cucullata (OPGC 424), B. echinosepala Regel. var. elongatifolia (OPGC 426), $B$. holtonis A. DC. (OPGC 712), B. foliosa Kunth var. miniata (OPGC 851), and B. 'Fuchsifoliosa' (B. foliosa x B. folia) (OPGC 852) are among some of the begonia species being held at the OPGC that have a high ornamental potential and are easy to propagate by stem cuttings. The OPGC does not have complete information regarding the specific locations 
and environmental conditions present where these species were collected. Thompson and Thompson in 1981 [7] provide the following description of these begonias: Begonia albopicta, a cane-like begonia that originated in Brazil, grows well indoors and in outdoor gardens. Begonia cucullata var. cucullata is a widespread South American species used as the original parent of most hybrid semperflorens or bedding begonias. Begonia echinosepala var. elongatifolia, B. holtonis and B. foliosa var. miniata originated in Brazil, Colombia and Mexico, respectively, and are classified as small, bare-leaf, shrub-like species . Begonia foliosa var. miniata and $B$. 'Fuchsifoliosa' prefer shady locations or those that receive mottled sunlight. The objective of this study was to evaluate the response of these five begonia species and one interspecific hybrid conserved at the OPGC to different fertilizer concentrations and substrate $\mathrm{pH}$ levels.

\section{MATERIALS AND METHODS}

\section{Plant Materials}

Tip cuttings with 3 to 5 leaves were harvested from each stock plant and planted in 48-cell pack trays using a soilless substrate consisting of $50 \%(\mathrm{v}: \mathrm{v})$ coarse perlite (Horticultural Perlite, Therm-O-Rock East, Inc) and 50\% Metro Mix 360 (The Scotts Co., Marysville, OH). Cuttings were kept on a propagation mist bench for 40 days for rooting.

\section{EXPERIMENT I - RESPONSE TO FERTILIZER CONCENTRATIONS}

\section{Growing Conditions}

Rooted cuttings of the six Begonia species were transplanted into $11.4 \mathrm{~cm}$ diameter round plastic containers with the soilless substrate, Metro Mix 360 (The Scotts Co., Marysville, $\mathrm{OH}$ ), consisting of Canadian sphagnum peat moss (10 to $20 \%$ ), vermiculite (25 to $40 \%$ ), horticultural grade perlite ( 5 to $15 \%$ ), bark ash ( 0 to $10 \%$ ), pine bark ( 25 to $45 \%$ ) with starter nutrient charge, dolomitic limestone and long-lasting wetting agent. Plants were top irrigated with a graduated cylinder using either 20,80, 200, 400, or 600 $\mathrm{mg} \cdot \mathrm{L}^{-1} \mathrm{~N}$ fertilizer solutions of $17 \mathrm{~N}-2.2 \mathrm{P}-14.1 \mathrm{~K}$ (Greencare $17 \mathrm{~N}-5 \mathrm{P}_{2} \mathrm{O}_{5}-17 \mathrm{~K}_{2} \mathrm{O}$, Kankakee, IL). The fertilizer solutions were prepared with tap water having an EC of $0.31 \mathrm{mS} \cdot \mathrm{cm}^{-1}$ Final EC levels of each solution were 0.44, 0.80, 1.59, 2.88, or $4.15 \mathrm{mS} \cdot \mathrm{cm}^{-1}$ for the $20,80,200,400$, or $600 \mathrm{mg} \cdot \mathrm{L}^{-1} \mathrm{~N}$ respectively. The fertigation was done as needed according to each species. It started with a frequency of twice a week and increased to daily applications towards the end of the experiment. Volumes of $237 \mathrm{ml}$ of fertilizer solutions applied per pot were sufficient to have a leaching fraction of approximately 0.25 to 0.30 . These leaching fractions have been proven over the years to prevent any salt built up under our growing conditions. Plants were grown for 12 weeks (June to September) in a greenhouse with a glass roof and under $40 \%$ knitted shade fabric (A.M. Leonard, Piqua, $\mathrm{OH}$ ) to prevent plants from sunburn. Substrate EC was measured weekly using the pour-through extraction method [6]. This method consists on taking the substrate to container capacity one hour before measurement. After that time, enough distilled water is added to the substrate to collect $50 \mathrm{ml}$ of leachate from the pot by locating it on a saucer like collection vessel. EC and $\mathrm{pH}$ are measured on this collected solution and interpretation of the results is done using a table specifically developed for this method [6].

\section{Measurements}

The number of inflorescences (NI) was recorded weekly after the flowers of each inflorescence appeared. At the end of the experiment, leaves at the third node of two to five stems per plant were randomly selected and a SPAD chlorophyll meter (Minolta SPAD-502 meter, Spectrum Technologies, Plainfield, IL) was used at 15 to 20 randomly chosen locations in the selected leaves to determine relative leaf greenness. Shoot length (SL), total leaf area (LA), and shoot dry weight (DW) of all plants were also measured. Shoot length was defined as the length from the surface of the substrate to the tip of the longest shoot of each plant. Total leaf area was measured using a LI-COR 3100 leaf area meter (LI-COR, Lincoln, NE). All above ground plant parts for DW measurement were harvested and dried in a forcedair oven at 55 to $60^{\circ} \mathrm{C}$ for 5 days. In addition, visual observations of leaf chlorosis, necrosis, deformed leaves, and plant mortality were recorded throughout the experiment. For the purposes of this study, the term "quality' includes a subjective combination 1) plant growth characteristics such as dry weight, stem length, total leaf area, number of inflorescences, SPAD readings, and 2) visual observation of leaf chlorosis, necrosis, sunburn, deformed leaves, and plant mortality.

\section{EXPERIMENT II - RESPONSE TO SUBSTRATE PH}

\section{Treatments - Soilless Media}

The components of the basic substrate were $70 \%$ Canadian sphagnum peat moss (Premier Pro Moss, Premier Horticulture Inc, Red Hill, PA) and 30\% coarse perlite (Horticultural Perlite, Therm-O-Rock East, Inc). The preplant nutrient charge consisted of $0.6 \mathrm{~kg} \cdot \mathrm{m}^{-3}$ of $6 \mathrm{~N}-3.96 \mathrm{P}-$ $7.47 \mathrm{~K}$ fertilizer (Greencare $6 \mathrm{~N}-9 \mathrm{P}_{2} \mathrm{O}_{5}-9 \mathrm{~K}_{2} \mathrm{O}-10 \mathrm{Ca}-1 \mathrm{Mg}$, Chicago, IL), $0.6 \mathrm{~kg} \cdot \mathrm{m}^{-3}$ of gypsum $\left(\mathrm{CaSO}_{4}\right)$, and $0.29 \mathrm{~kg} \cdot \mathrm{m}^{-3}$ of $\mathrm{MgSO}_{4} \cdot 7 \mathrm{H}_{2} \mathrm{O}$ (Greencare, Chicago, IL). A wetting agent (Aqua-Gro L with PsiMatric TM Technology, Scotts, Marysville, $\mathrm{OH}$ ) was also added at $0.25 \mathrm{~L}_{\text {per }} \mathrm{m}^{-3}$ of substrate. The basic substrate was mixed with $0,1.0,1.3,1.6$, $2.0,2.4$, and $2.7 \mathrm{~kg} \cdot \mathrm{m}^{-3}$ of dolomitic hydrated lime to reach seven targeted substrate $\mathrm{pH}$ ranges: $<4.5,4.5$ to $5.0,5.0$ to $5.5,5.5$ to $6.0,6.0$ to $6.5,6.5$ to 7.0 and $>7.0$ ). The substrates were prepared using a cement mixer.

\section{Growing Conditions}

Rooted cuttings of the selected Begonia species were transplanted into $11.4 \mathrm{~cm}$ diameter round plastic containers with the seven prepared substrates. Plants were top irrigated using a $17 \mathrm{~N}-2.2 \mathrm{P}-14.1 \mathrm{~K}$ (Greencare $17 \mathrm{~N}-5 \mathrm{P}_{2} \mathrm{O}_{5}-17 \mathrm{~K}_{2} \mathrm{O}$, Kankakee, IL) fertilizer solution at a rate of $200 \mathrm{mg} \cdot \mathrm{L}^{-1} \mathrm{~N}$, twice a week at the beginning, to daily at the end of the experiment. The fertilizer solution was prepared with tap water having an alkalinity level of $79 \mathrm{mg} \cdot \mathrm{L}^{-1}$ expressed as calcium carbonate. After transplanting, substrate $\mathrm{pH}$ was measured weekly using the pour-through extraction method [6]. When the measured substrate $\mathrm{pH}$ was higher than the 
targeted substrate $\mathrm{pH}$ range, a diluted sulfuric acid $\left(\mathrm{H}_{2} \mathrm{SO}_{4}\right)$ solution was mixed with the fertilizer solution for fertigation. When the measured substrate $\mathrm{pH}$ was lower than the targeted substrate $\mathrm{pH}$ range, a dolomitic hydrated lime solution was applied to the media surface. Plants were grown for 12 weeks (June to August) in a glass greenhouse under a $40 \%$ knitted shade fabric (A.M. Leonard, Piqua, $\mathrm{OH}$ ) to protect plants from sunburn damage.

\section{Experiment Design and Data Analysis}

Plants in Experiment I (5 fertilizer concentrations $\times 6$ begonia species) and $I I$ ( 7 targeted substrate $\mathrm{pH} \times 6$ begonia species) were arranged in a randomized complete block design. Six blocks of each experiment were located on two benches in the same greenhouse compartment. The measured growth characteristics (SL, LA, NI and DW) and foliage greenness (SPAD) were subjected to analysis of variance (ANOVA) using the GLM Procedure of Enterprise Guide 3.0 of the Statistical Analysis Software (SAS Institute, Cary, $\mathrm{NC})$. In addition, linear and quadratic models were fitted to the response of each growth characteristic as a function of fertilizer concentration or substrate $\mathrm{pH}$. When the fitting of both (linear and quadratic) models was significant $(P \leq 0.05)$, the one resulting in the larger coefficient of determination $\left(\mathrm{R}^{2}\right)$ was plotted.

\section{RESULTS AND DISCUSSION}

\section{- Response to Fertilizer Concentration}

Significant interactions between fertilizer concentrations and begonia species on substrate EC and all growth characteristics measured were found $(P \leq 0.01$ or 0.0001 , Table 1). Therefore, the response of six begonia species to different fertilizer concentrations on substrate EC, NI, SPAD, SL, LA, and DW were separately analyzed for each species. The initial substrate EC measured after the first irrigation using tap water at transplanting was between 1.4 to $1.9 \mathrm{mS} \cdot \mathrm{cm}^{-1}$ (Fig. 1). As soon as the plants were fertigated with the various solutions, substrate EC increased immediately in most treatments, except for the 20 and $80 \mathrm{mg} \cdot \mathrm{L}^{-1} \mathrm{~N}$ rates (Fig. 1).
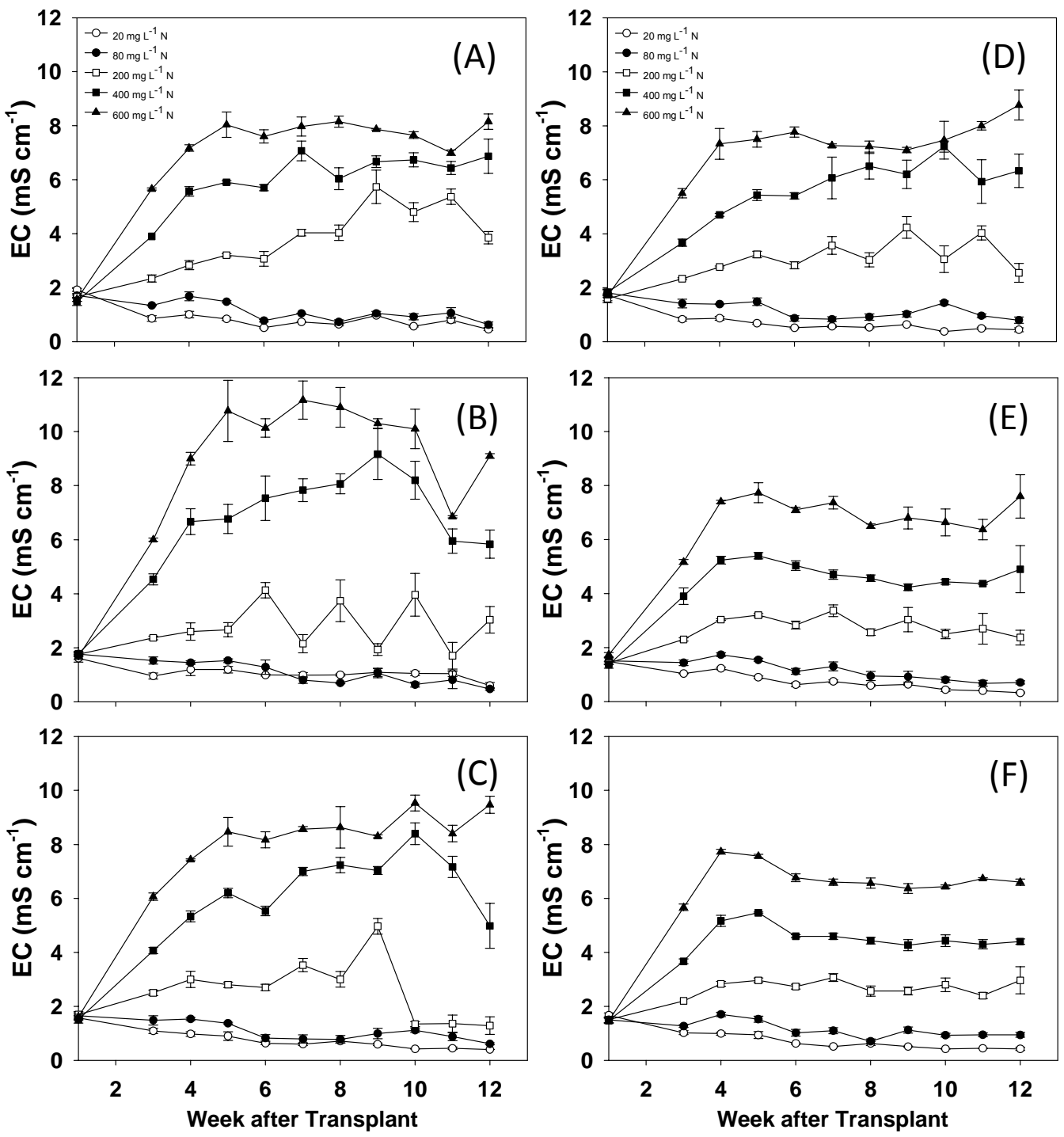

Fig. (1). Weekly measured substrate electrical conductivity (EC) for begonia species (A): B. albopicta, (B): B. cucullata var. cucullata, (C): B. echinosepala var. elongatifolia, (D): B. holtonis, (E): B. foliosa var. miniata, and (F): B. 'Fuchsifoliosa' fertigated with 20, 80, 200, 400 or $600 \mathrm{mg} \cdot \mathrm{L}^{-1} \mathrm{~N} .(\mathrm{n}=3$, Error bar $=\mathrm{SE})$. 
Table 1. Summary Analysis of Variance Table for the Impact of Fertilizer Concentration, Begonia Species and the Interaction between Fertilizer Concentration and Begonia Species on Substrate Electrical Conductivity (EC), Number of Inflorescences (NI), SPAD Readings (SPAD), Shoot Length (SL), Leaf Area (LA), Dry Weight (DW)

\begin{tabular}{|c|c|c|c|c|c|c|}
\hline Factors & Substrate EC & NI & SPAD & SL & LA & DW \\
\hline $\begin{array}{c}\text { Fertilizer } \\
\text { Concentration (F) }\end{array}$ & $* * *$ & $* * *$ & $* * *$ & $* * *$ & $* * *$ & $* * *$ \\
\hline Begonia Species (B) & $* * *$ & $* * *$ & $* * *$ & $* * *$ & $* * *$ & $* * *$ \\
\hline $\mathrm{F} \times \mathrm{B}$ & $* * *$ & ** & $* * *$ & $* * *$ & $* * *$ & ** \\
\hline
\end{tabular}

In fact, the weekly measured substrate EC levels for these two lower fertilization rates decreased over time. When the applied fertilizer solution was 200,400 , or $600 \mathrm{mg} \cdot \mathrm{L}^{-1} \mathrm{~N}$, the substrate EC levels of all species increased for approximately four to five weeks; they then remained relatively constant except for B. cucullata var. cucullata and $B$. echinosepala var. elongatifolia (Fig. 1).

The final substrate EC level ranged within 0.32 to 9.5 $\mathrm{mS} \cdot \mathrm{cm}^{-1}$. Whipker et al. in 1999 [8] found that root substrate
EC was significantly affected by fertilizer concentrations and different cultivars over time. The final substrate EC at each fertilizer concentration treatment was significantly different depending on species perhaps as a consequence of differential water and nutrient uptake by the species. In a future study, water use efficiency and tissue analysis should be measured to confirm this. The final substrate EC at 600 $\mathrm{mg} \cdot \mathrm{L}^{-1} \mathrm{~N}$ was above $9.0 \mathrm{mS} \cdot \mathrm{cm}^{-1}$ for $B$. cucullata var. cucullata and B. echinosepala var. elongatifolia, while 6.3 for B. holtonis and 6.6 for B. foliosa var. miniata.

Substrate EC with 20 and $80 \mathrm{mg} \cdot \mathrm{L}^{-1} \mathrm{~N}$ were very similar for B. albopicta, B. cucullata var. cucullata, B. echinosepala var. elongatifolia (Fig. 1, A-C). Similarly, Whipker et al. (1999) [8] found that there were no significant differences in substrate EC when 'Purple Magic' double impatiens were grown at 50 or $100 \mathrm{mg} \cdot \mathrm{L}^{-1} \mathrm{~N}$. Since substrate EC indicates available salts (nutrients), it is likely that most nutrients applied with the 20 or $80 \mathrm{mg} \cdot \mathrm{L}^{-1} \mathrm{~N}$ solution were absorbed by the plants. As a result, the additional nutrients provided at the $80 \mathrm{mg} \cdot \mathrm{L}^{-1} \mathrm{~N}$ resulted in higher plant quality and growth compared with the plants irrigated with $20 \mathrm{mg} \cdot \mathrm{L}^{-1} \mathrm{~N}$ solution (Figs. 2-7).

Most plant growth characteristics had significant quadratic responses to increasing fertilizer concentrations (Figs.
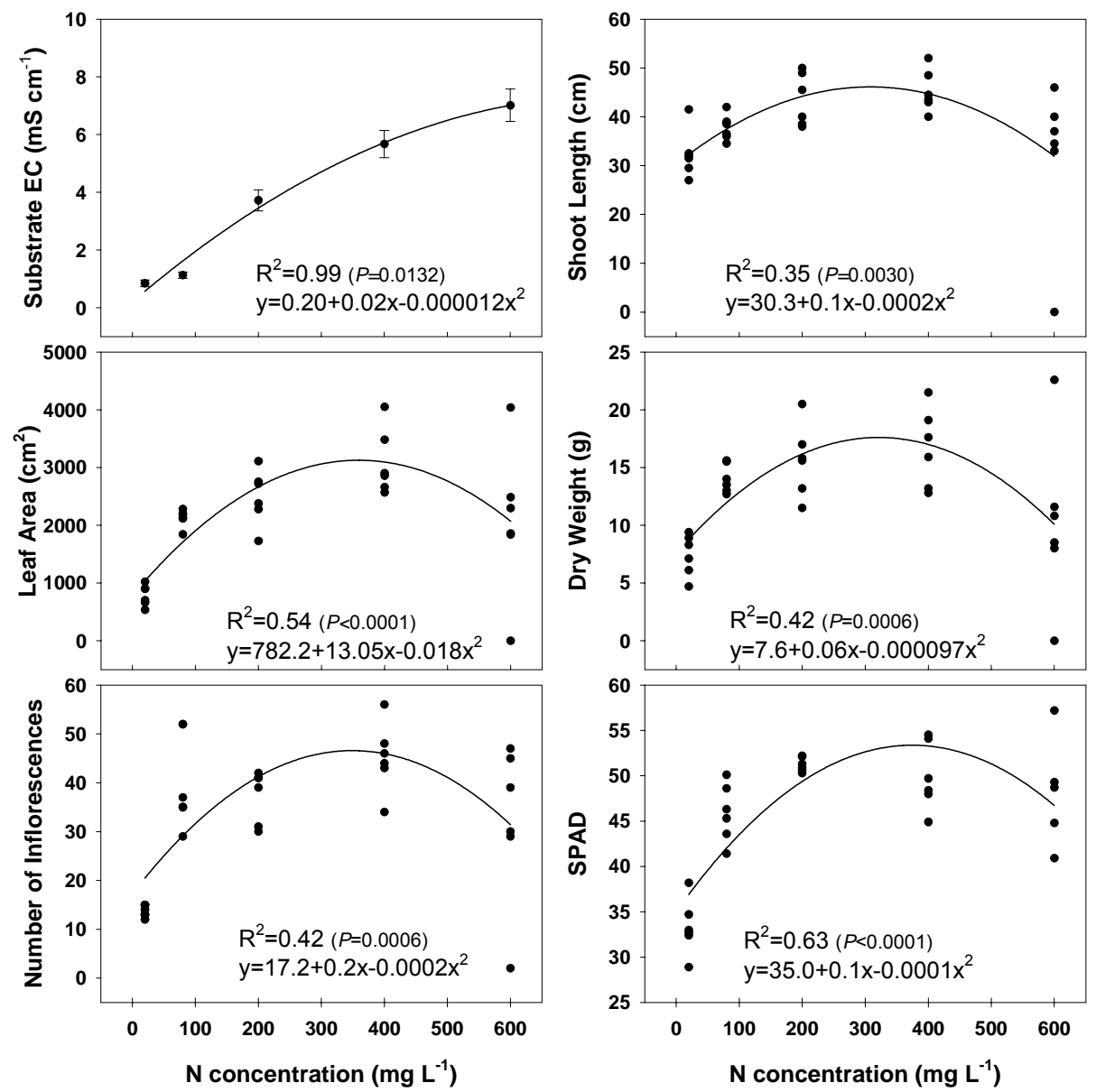

Fig. (2). Begonia albopicta - Observed (symbols) and predicted (lines) substrate electrical conductivity at 12 weeks after transplanting, shoot length, leaf area, dry weight, average number of inflorescences, and SPAD of B. albopicta plants as a function of fertilizer concentration expressed as $\mathrm{mg} \cdot \mathrm{L}^{-1} \mathrm{~N}$. All quadratic models were significant (at $P \leq 0.05$ ). 

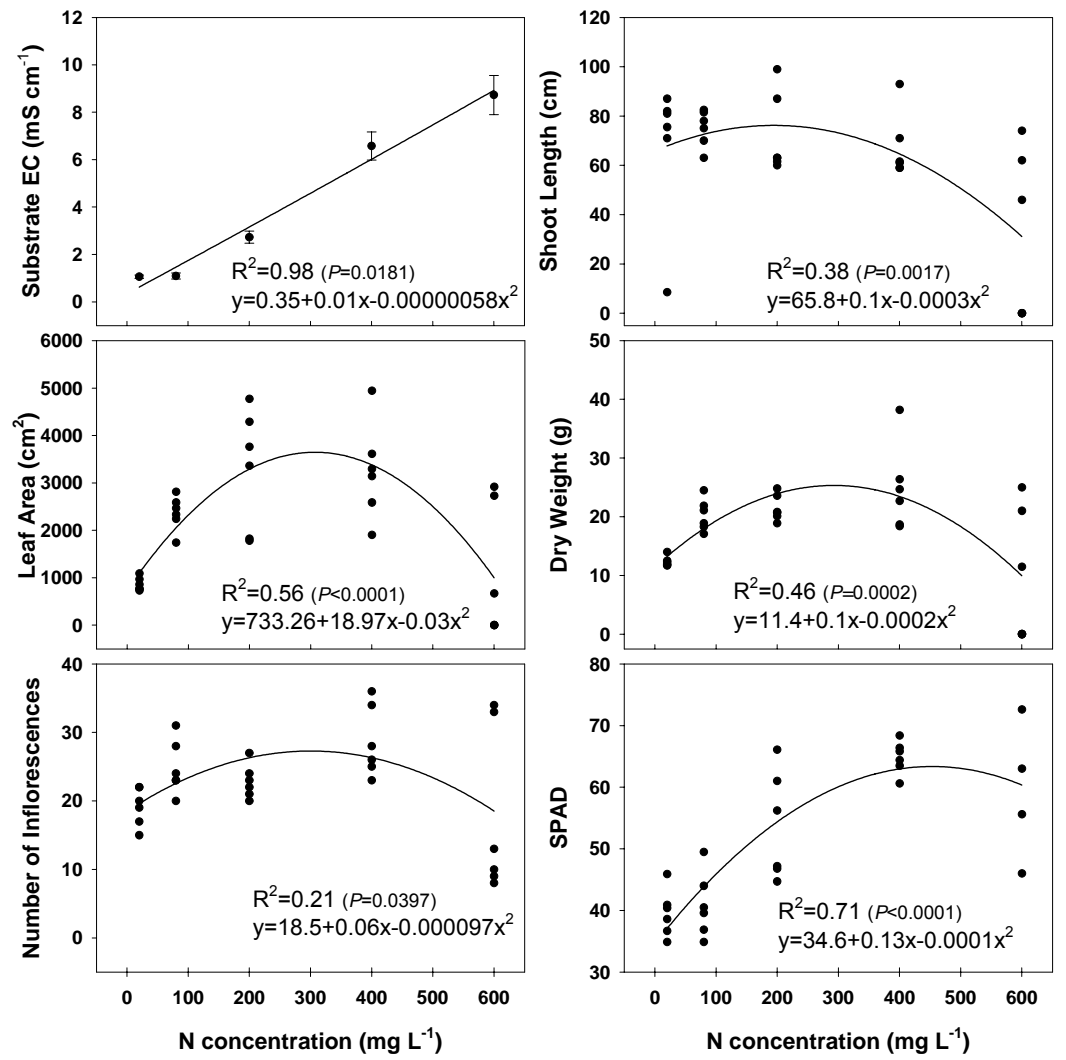

Fig. (3). Begonia cucullata var. cucullata - Observed (symbols) and predicted (lines) substrate electrical conductivity at 12 weeks after transplanting, shoot length, leaf area, dry weight, average number of inflorescences, and SPAD as a function of fertilizer concentration expressed as $\mathrm{mg} \cdot \mathrm{L}^{-1} \mathrm{~N}$. All quadratic models were significant (at $P \leq 0.05$ ).
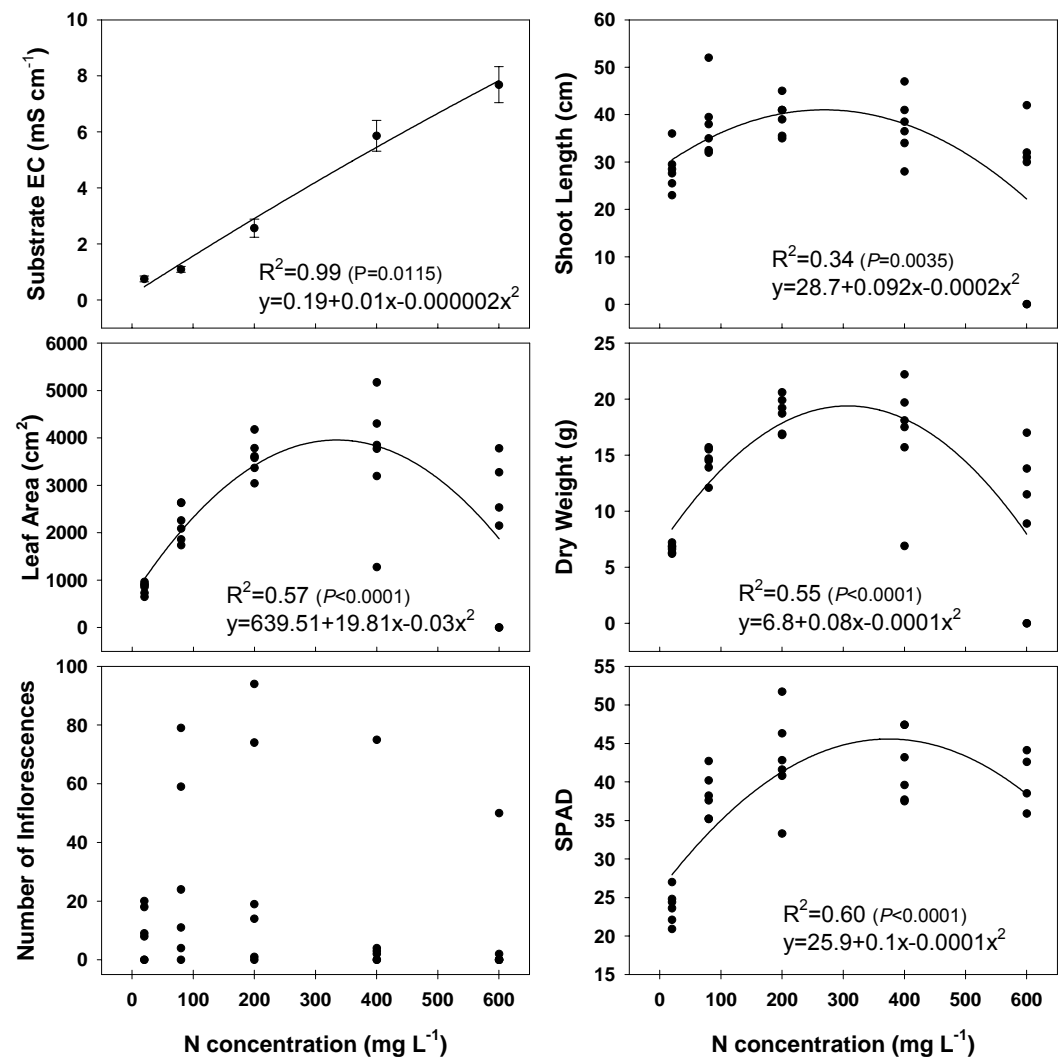

Fig. (4). Begonia echinosepala var. elongatifolia - Observed (symbols) and predicted (lines) substrate electrical conductivity at 12 weeks after transplanting, shoot length, leaf area, dry weight, average number of inflorescences, and SPAD as a function of fertilizer concentration expressed as $\mathrm{mg} \cdot \mathrm{L}^{-1} \mathrm{~N}$. All quadratic fitting models were significant (at $P \leq 0.05$ ) except for number of inflorescences. 

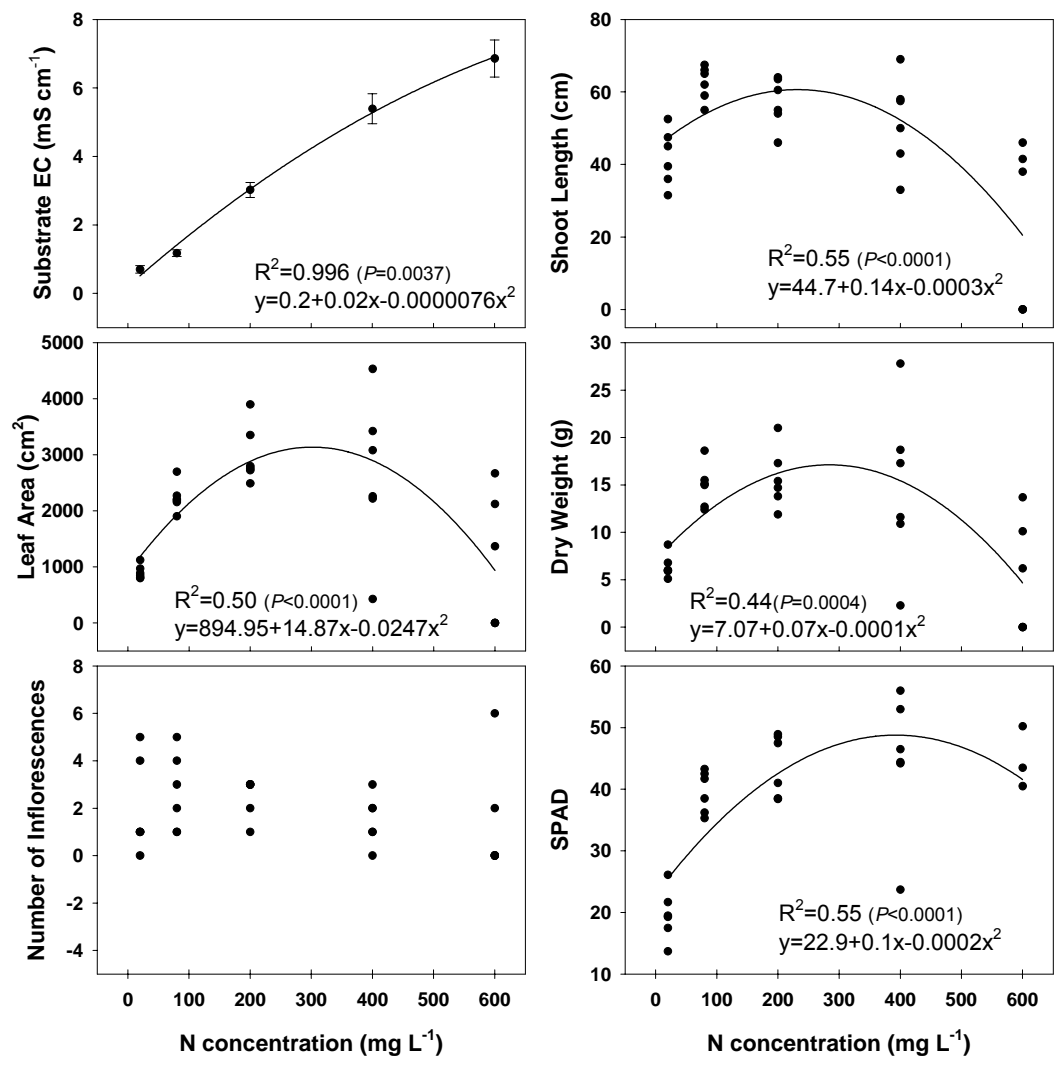

Fig. (5). Begonia holtonis - Observed (symbols) and predicted (lines) substrate electrical conductivity at 12 weeks after transplanting, shoot length, leaf area, dry weight, average number of inflorescences, and SPAD of B. holtonis plants as a function of fertilizer concentration expressed as $\mathrm{mg} \cdot \mathrm{L}^{-1} \mathrm{~N}$. All quadratic models were significant (at $P \leq 0.05$ ) except for number of inflorescences.

2-7). Exceptions were number of inflorescences of $B$. echinosepala var. elongifolia (Fig. 4), B holtonis (Fig. 5), $B$. 'Fuchsifoliosa' (Fig. 7), and DW of $B$. 'Fuchsifoliosa' (Fig. 7). Although the $P$ values indicated highly significant responses, the coefficient of determinations $\left(\mathrm{R}^{2}\right)$ ranged between 21 and 74\% (Figs. 2-7). The maximum NI for B. albopicta, and B. cucullata var. cucullata was measured at $400 \mathrm{mg} \cdot \mathrm{L}^{-1} \mathrm{~N}$ (Figs. 2 and 3). On the other hand, B. foliosa var. cuculata had a negative response of flowering to fertilizer concentration increase (Fig. 6).

At 400 and $600 \mathrm{mg} \cdot \mathrm{L}^{-1} \mathrm{~N}$, inflorescence size and flower number per inflorescence were visually smaller for most begonia species. This reduction is in agreement with results presented by Chase and Poole in 1987 [9], who found that when plants were irrigated with increasing fertilizer concentrations, the flower number in fibrous-rooted begonia 'Prelude Red' was reduced. In addition, the apparent increase in inflorescence size and in number of flowers per inflorescence found on plants fertigated with 20 to $80 \mathrm{mg} \cdot \mathrm{L}^{-1}$ $\mathrm{N}$ is in line with results from Whipker et al., in 1999 [5] who reported that plants fertigated with $50 \mathrm{mg} \cdot \mathrm{L}^{-1} \mathrm{~N}$ produced the highest number of blooms per unit leaf area, although plants were small. Thus, the optimal fertilizer concentration for maximum plant growth was higher than the one for maximum flower size and number of flowers per inflorescence.

Flower color of B. albopicta plants was also affected by fertilizer concentrations. At 20 and $80 \mathrm{mg} \cdot \mathrm{L}^{-1} \mathrm{~N}$, the inflorescences had pink flowers, as opposed to only white flowers at the 400 and $600 \mathrm{mg} \cdot \mathrm{L}^{-1} \mathrm{~N}$. Joiner and Smith [10] reported in 1960 that flower color of Chrysanthemum morifolium, 'Bluechip' became lighter with increasing $\mathrm{N}$ concentration in the applied fertilizer solution. They found that significant color fading occurred when $\mathrm{N}$ concentration increased from 200 to $400 \mathrm{mg} \cdot \mathrm{L}^{-1} \mathrm{~N}$, and the palest flowers occurred at the highest $\mathrm{N}$ level $\left(400 \mathrm{mg} \cdot \mathrm{L}^{-1} \mathrm{~N}\right)$.

All begonia species plants fertigated with $600 \mathrm{mg} \cdot \mathrm{L}^{-1} \mathrm{~N}$ experienced some mortality ranging from $16.7 \%$ for $B$. albopicta, $33.3 \%$ for $B$. echiinosepala var. elongatifolia, $50 \%$ for B. cucullata var. cucullata, B. holtonis, and $B$. 'Fuchsifoliosa', and $83.8 \%$ for $B$. foliosa var. miniata. In addition, $83.8 \%$ mortality was observed when $B$. foliosa var. miniata plants were grown at $400 \mathrm{mg} \cdot \mathrm{L}^{-1} \mathrm{~N}$, and $16.7 \%$ mortality was observed in $B$. 'Fuchsifoliosa' plants grown at 200 and $400 \mathrm{mg} \cdot \mathrm{L}^{-1} \mathrm{~N}$. It is not possible to explain the observed mortality because chemical analyses of plant tissue and substrate were not conducted. Possible mortality causes may include increasing susceptibility to pathogens caused by osmotic shock or specific ion toxicities.

All begonia plants fertilized with 20 and $80 \mathrm{mg} \cdot \mathrm{L}^{-1} \mathrm{~N}$ had uniform chlorosis on the old leaves with the exception of $B$. foliosa var. miniata and $B$. 'Fuchsifoliosa' plants at 80 $\mathrm{mg} \cdot \mathrm{L}^{-1} \mathrm{~N}$. This chlorosis was consistent with typical $\mathrm{N}$ deficiency symptoms. When $B$. cucullata var. cucullata plants were grown using 400 and $600 \mathrm{mg} \cdot \mathrm{L}^{-1} \mathrm{~N}$, distortion of young leaves, leaf puckering and leaf necrosis were frequently observed. B. echinosepala var. elongatifolia plants fertigated 

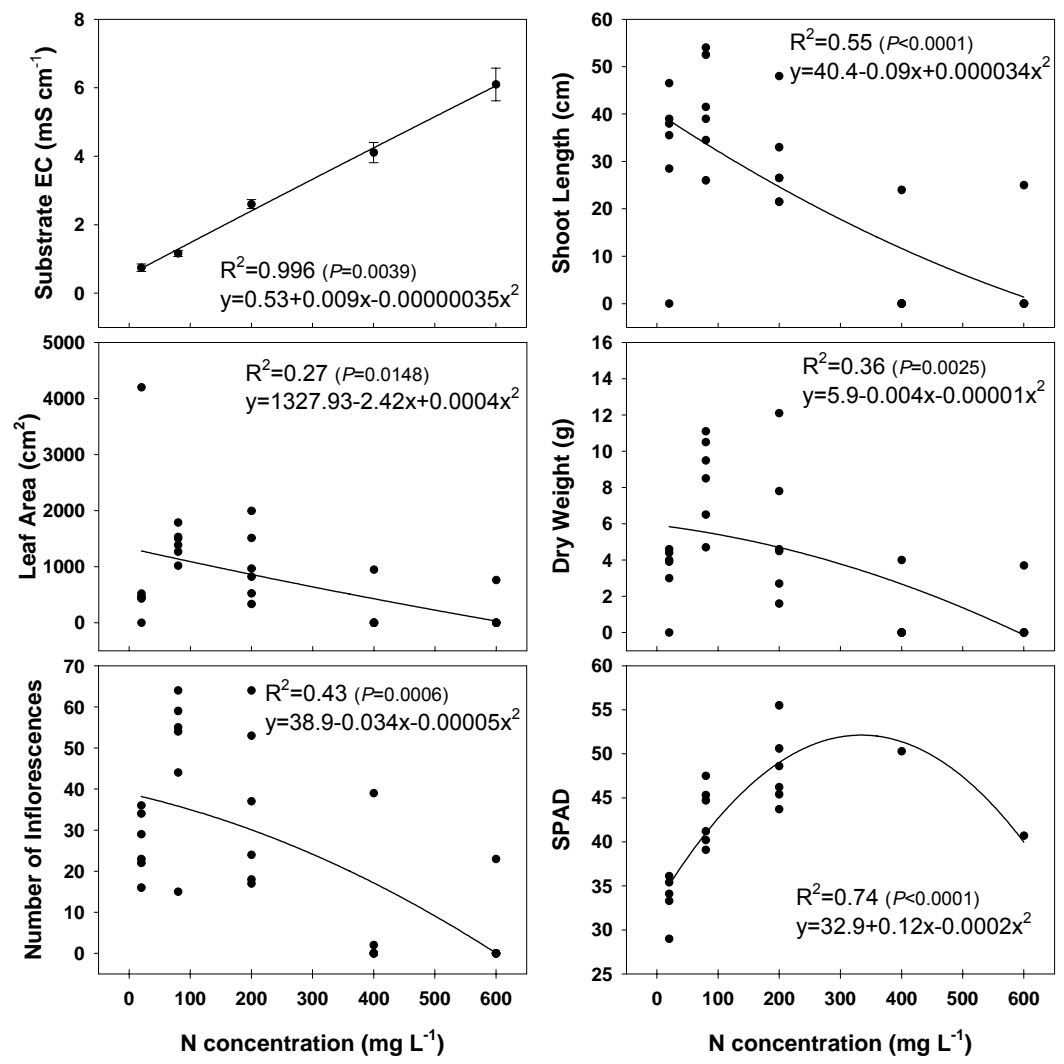

Fig. (6). Begonia foliosa var. miniata - Observed (symbols) and predicted (lines) substrate electrical conductivity at 12 weeks after transplanting, shoot length, leaf area, dry weight, average number of inflorescences, and SPAD as a function of fertilizer concentration expressed as $\mathrm{mg} \cdot \mathrm{L}^{-1} \mathrm{~N}$. All quadratic models are significant (at $P \leq 0.05$ ).
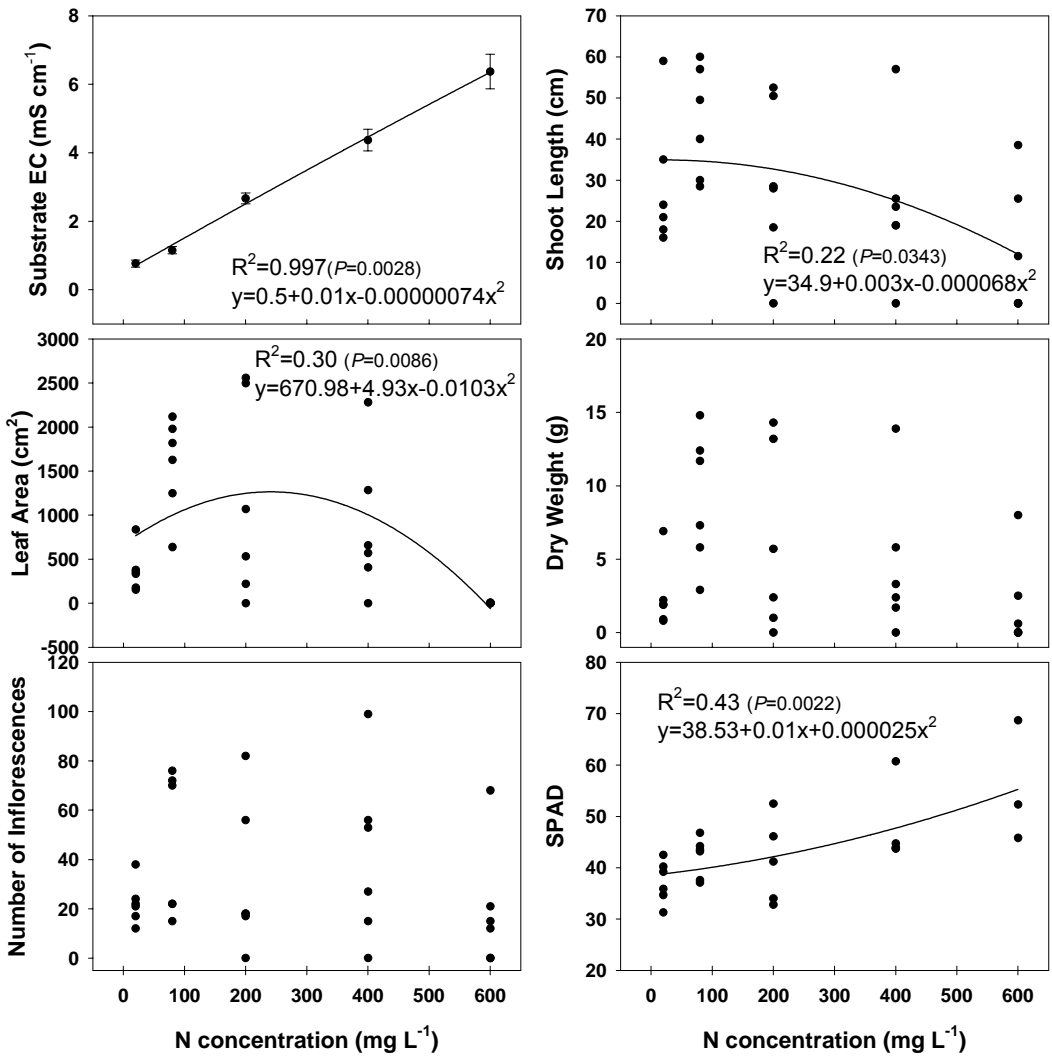

Fig. (7). Begonia 'Fuchsifoliosa' - Observed (symbols) and predicted (lines) substrate electrical conductivity at 12 weeks after transplanting, shoot length, leaf area, dry weight, average number of inflorescences, and SPAD as a function of fertilizer concentration expressed as $\mathrm{mg} \cdot \mathrm{L}^{-1}$ N. All quadratic models are significant (at $P \leq 0.05$ ) except for number of inflorescences. 
with $20 \mathrm{mg} \cdot \mathrm{L}^{-1} \mathrm{~N}$ had cupping leaves. The leaf puckering was also observed when $B$. holtonis, $B$. foliosa var. miniata and $B$. 'Fuchsifoliosa' plants were fertigated with 200, 400, or $600 \mathrm{mg} \cdot \mathrm{L}^{-1} \mathrm{~N}$.

Based on all measured plant growth characteristics, optimal fertilizer concentrations were determined. High quality B. albopicta, B. cucullata var. cucullata, B. echinosepala var. elongatifolia, and $B$. holtonis plants were observed when they were fertigated with 200 to $300 \mathrm{mg} \cdot \mathrm{L}^{-1} \mathrm{~N}$. On the other hand, low fertilizer concentration was recommended for $B$. foliosa var. miniata and $B$. 'Fuchsifoliosa' to avoid high salt stress possibly causing plant death. B. cucullata var. cucullata, B. foliosa var. miniata and B. 'Fuchsifoliosa' plants were more sensitive to salt stress than the other species. This response is consistent with reports by Cavins et al. (2000), indicating that begonia requires low substrate EC: 1.0 to $2.6 \mathrm{mS} \cdot \mathrm{cm}^{-1}$ for optimal growth. In this study, $B$. albopicta, B. echinosepala var. elongatifolia, and B. holtonis behaved as more salt-tolerant, with no mortality up to 400 $\mathrm{mg} \cdot \mathrm{L}^{-1} \mathrm{~N}$. A high substrate EC $\left(5.4\right.$ to $\left.5.9 \mathrm{mS} \cdot \mathrm{cm}^{-1}\right)$ did not significantly affect growth of these species, with the exception of reducing the size of flowers and inflorescences.
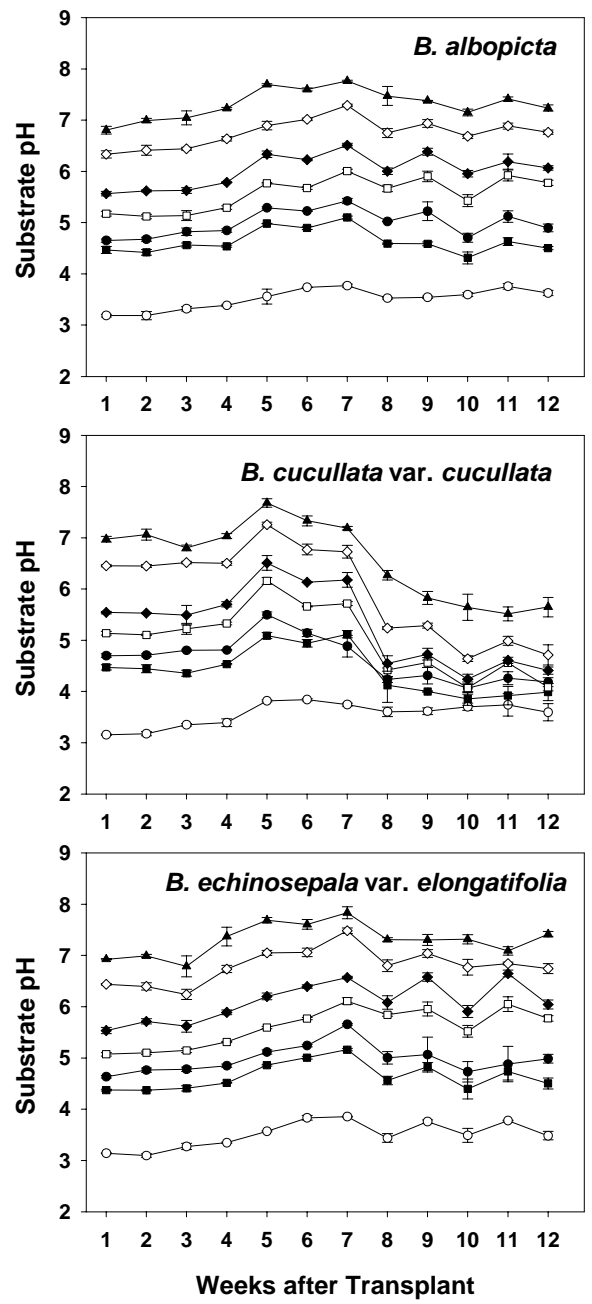

\section{-Response to Substrate pH}

The acidity of the substrate without lime $(\mathrm{pH}=3.3)$ was comparable to the one reported by Bishko and Fisher in 2002 [11] under similar circumstances $(\mathrm{pH}=3.4)$. The substrate $\mathrm{pH}$ increased with increasing dolomitic hydrated lime rate (Fig. 8), in agreement with results presented by Haynes in 1982 [12], Wiedenfeld and Cox in 1988 [13], and Bishko and Fisher in 2002 [11] who also attained higher substrate $\mathrm{pH}$ with increasing amounts of lime applied to soilless media.

The initial substrate $\mathrm{pH}$ (week 1) remained relatively constant until week 3 for most species (Fig. 8). Between weeks 3 and $7 \mathrm{pH}$ increased for most species and then either decreased or remained relatively constant with the exception of $B$. cucullata var. cucullata. Only the lowest target $\mathrm{pH}$ level for B. cucullata var. cucullata was within target range (below 4.5) while the other substrate $\mathrm{pH}$ levels were lower than target ranges (Fig. 8). Thus, data collected on this species were discarded. A possible explanation for this $\mathrm{pH}$ drop has been the size of the container and the vigor of this species. As plants grew, the high density of the roots in a limited substrate volume resulted in dry substrates despite daily watering. When peat-based substrates dry out in the
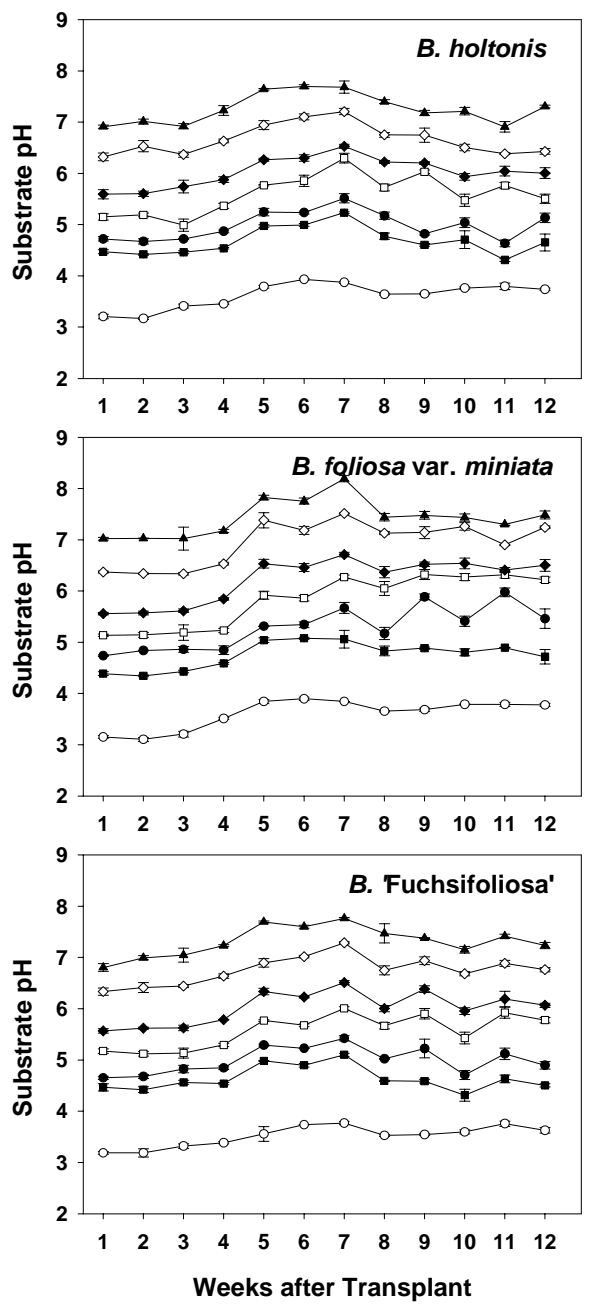

Fig. (8). Weekly measured substrate $\mathrm{pH} \pm \mathrm{SD}$ of the six substrates treated with different amount of hydrated dolomitic lime. Symbols, $\circ$, $\square$, $\bullet, \square, \diamond, \diamond$, and $\boldsymbol{\Delta}$, indicate substrate treated with $0,1.0,1.3,1.6,2.0,2.4$, and $2.7 \mathrm{~kg} \cdot \mathrm{m}^{-3}$ of dolomitic hydrated lime, respective. Each point represents the mean of 3 replications. $(n=5$; Error bar $=\mathrm{SE})$. 

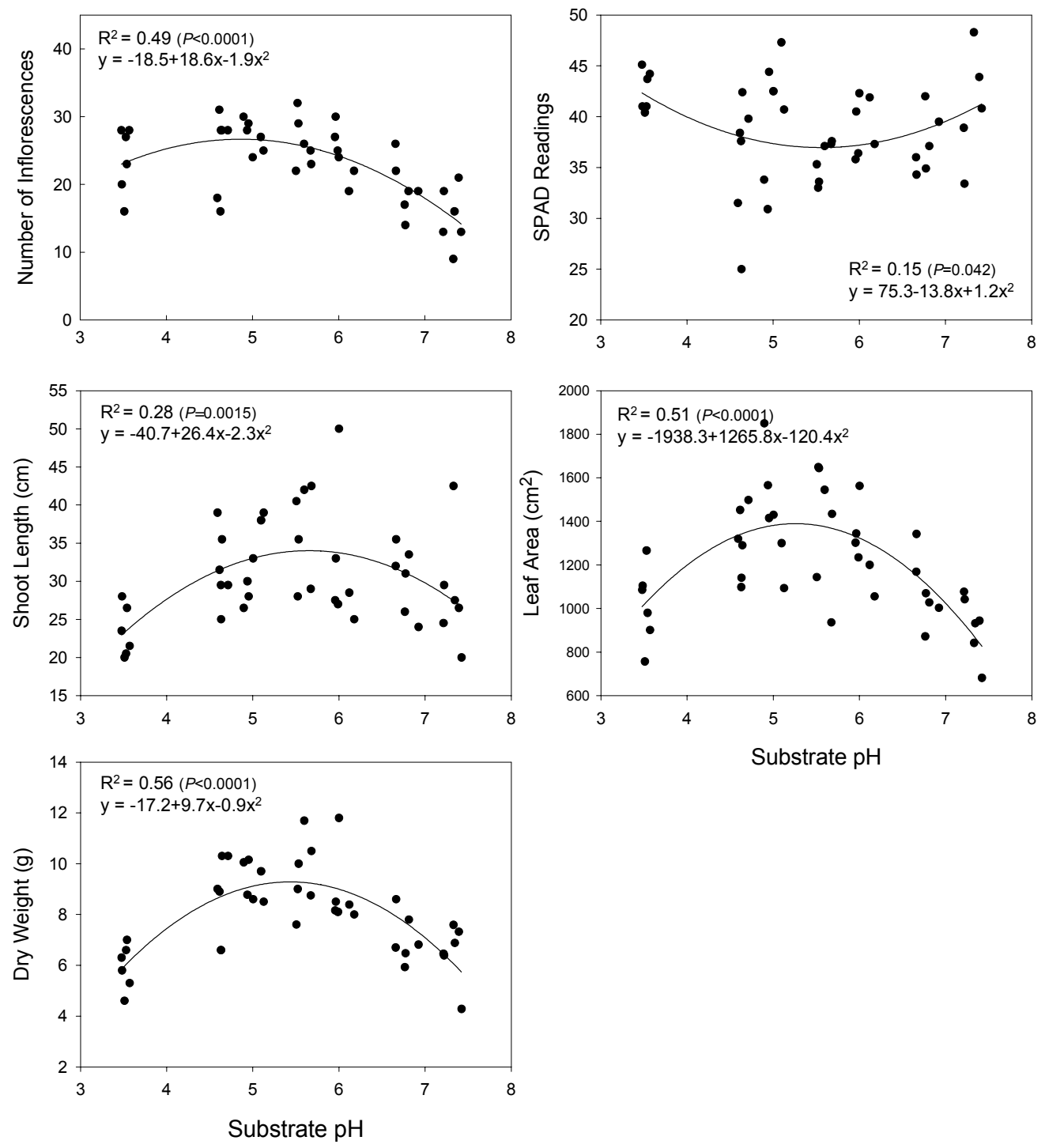

Fig. (9). B. albopicta - Observed (symbols) and predicted (lines) growth characteristics to substrate pH. Each data point represents one plant. All quadratic models are significant (at $P \leq 0.05$ ).

container, the applied water does not penetrate uniformly through the root ball [14]. When substrate $\mathrm{pH}$ levels were adjusted by drenching the lime solution into the pot, the solution most likely passed directly through the space between the root ball and the wall of the container. Water repellence due to a dry substrate (sometime called "channeling") made it impossible to maintain desired substrate $\mathrm{pH}$ levels over 12 weeks. For the other 5 species, average substrate $\mathrm{pH}$ over this period were within target.

Significant interactions between $\mathrm{pH}$ and species were found in shoot length, leaf area, and dry weight at $P<0.001$, 0.05 , and 0.01 , respectively. There was significant effect of species on average inflorescence number and SPAD readings. Only B. albopicta and B. holtonis were significantly responsive to substrate $\mathrm{pH}$, and almost all the plant growth characteristics of these two species had significant responses with increasing $\mathrm{pH}$ (Figs. 9 and 10). Although significant, the quadratic equations had most $R^{2}$ values below 0.5 . The other three species had no significant responses to substrate $\mathrm{pH}$ with the exceptions of SL of B. echinosepala var. elongifolia and LA of B. foliosa var. miniata (Fig. 11). Although significant, these two responses had very small $\mathrm{R}^{2}$ values: 0.17 and 0.18 respectively indicating that only a small portion of the variation could be explained by the substrate $\mathrm{pH}$.

When $B$. albopicta plants were grown at $\mathrm{pH}$ below 5.0, black necrotic speckles were frequently observed on leaves and petals. B. holtonis plants grown at $\mathrm{pH}$ below 5.0 had necrosis, chlorosis, and leaf puckering. Chlorotic, necrotic, and inward cupping leaves were frequently observed on $B$. echinosepala var. elongatifolia plants grown at $\mathrm{pH}$ below 5.0. In general, B. foliosa var. miniata and B. 'Fuchsifoliosa' plants grown at $\mathrm{pH}$ below 5.5 had brown or black necrotic speckles on leaves and inflorescences, and chlorotic leaves. When substrate $\mathrm{pH}$ was over 7.0, plants had puckering leaves without necrosis and chlorosis.

Although tissue analysis was not conducted in this experiment, the visual observations on plants grown at $\mathrm{pH}$ below 5.0 were similar to micronutrient toxicity and/or calcium and magnesium deficiency symptoms. Snowden and Wheeler in 

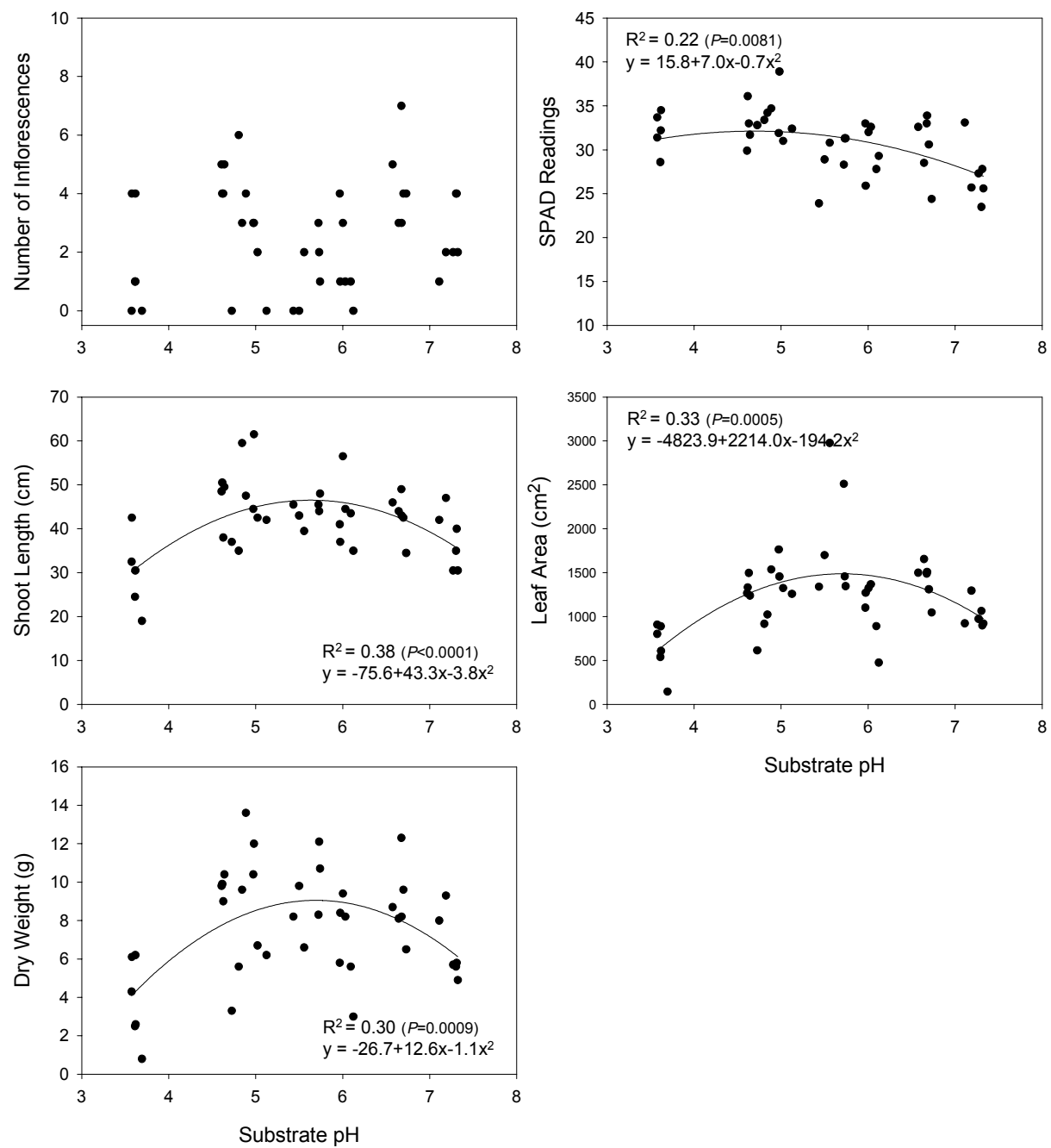

Fig. (10). B. holtonis - Observed (symbols) and predicted (lines) growth characteristics to substrate pH. Each data point represents one plant. All quadratic models are significant (at $P \leq 0.05$ ) except for number of inflorescences.
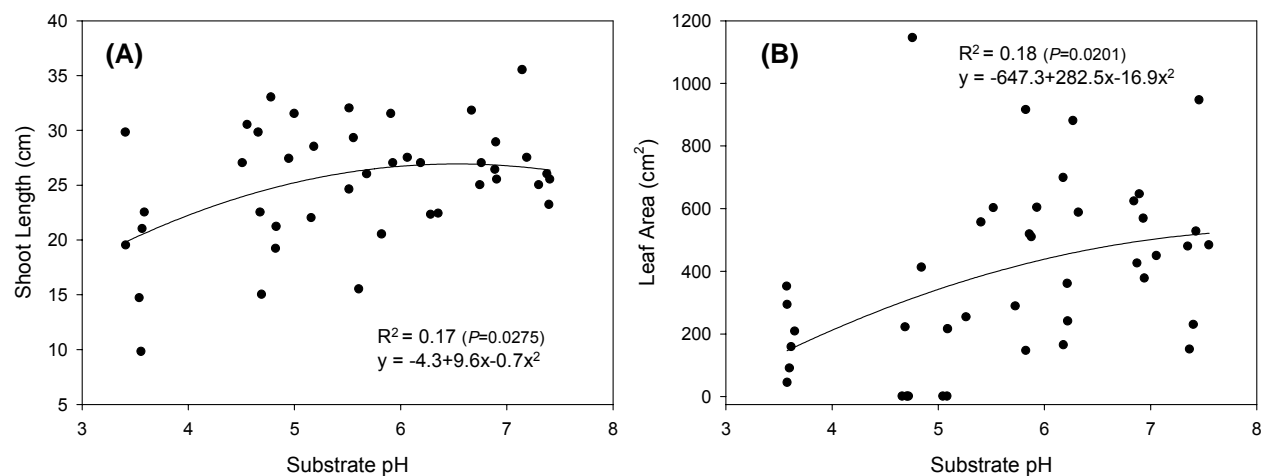

Fig. (11). B. echinosepala var. elongifolia (A) and B. foliosa var miniata (B) - Observed (symbols) and predicted (lines) growth characteristics to substrate $\mathrm{pH}$. Each data point represents one plant. All quadratic models are significant (at $P \leq 0.05)$.

1993 [15] and Argo and Fisher in 2003 [16] found that chlorosis and necrosis are typical symptoms of iron and manganese toxicity. The $28 \%$ mortality of $B$. foliosa var. miniata plants grown at a substrate $\mathrm{pH}$ below 5.2 could have resulted from toxic levels of micronutrients. Also, reduced plant growth and leaves with chlorosis and/or necrosis have been reported as calcium and magnesium deficiency symptoms $[17,2]$.
Soiless media $\mathrm{pH}$ affects the availability of nutrients to plants [14]. Most micronutrient toxicities and calcium and magnesium deficiencies are usually observed at low substrate $\mathrm{pH}[2]$. On the other hand micronutrient deficiencies are observed at high substrate $\mathrm{pH}[2,16]$. When average substrate $\mathrm{pH}$ of $B$. albopicta, B. echinosepala var. elongatifolia, and $B$. holtonis plants was higher than 5.6, there were no visual symptoms such as chlorosis or necrosis. Begonia 
species in this study were more susceptible to low than high substrate $\mathrm{pH}$.

The estimated optimal substrate $\mathrm{pH}$ for $B$. holtonis (5.7) and for B. albopicta (5.3 to 5.7) plants was slightly lower than the optimal substrate $\mathrm{pH}$ of 5.7 to 6.3 recommended by Cavins et al. in 2000 [6] for begonias in general. Growth characteristics measured on B. echinosepala var. elongatifoliosa plants were not significantly affected by substrate $\mathrm{pH}$, however, in order to avoid necrosis and small leaves in these plants, an average substrate $\mathrm{pH}$ above 5.6 should be used.

The information presented in this work clearly indicates that different Begonia species have different response to chemical substrate properties. Providing the proper levels of substrate $\mathrm{pH}$ and salt levels is important in order to maximize growth and maintain plant quality. These results will be useful to OPGC personnel in the maintenance of these species at their facilities, as well as to begonia breeders and collectors.

\section{ACKNOWLEDGEMENTS}

Publication of this manuscript was approved by the Department of Horticulture and Crop Science of The Ohio State University. Salaries and research support were provided by state and federal funds appropriated to The Ohio State University, Ohio Agricultural Research and Development Center as well as the Ornamental Plant Germplasm Center.

\section{REFERENCES}

[1] Nelson PV. Greenhouse operation and management, $6^{\text {th }} \mathrm{Ed}$. Prentice Hall, Upper Saddle River, N.J 2003.
[2] Bailey DA. Alkalinity, $\mathrm{pH}$, and acidification. In: a grower's guide to water, media, and nutrition for greenhouse crops. Reed DW. Ed, Ball Publishing, Batavia, Illinois. 1996; pp. 69-92.

[3] Wright RD. The pour-through nutrient extraction procedure. HortScience 1986; 21: 227-9.

[4] Peterson JC. Effects of $\mathrm{pH}$ upon nutrient availability in a commercial soilless root medium utilized for floral crop production. Ohio Agr Res and Devel Center Res Cir 1982; 268: 16-9.

[5] Whipker BE, Fonteno WC, Cavins TJ, Bailey DA. Pour-thru nutritional monitoring manual. North Carolina State University. $3^{\text {rd }}$ ed. 2000.

[6] Cavins TJ, Whipker BE, Fonteno WC, Harden B, McCall I, Gibson JL. Monitoring and managing $\mathrm{pH}$ and $\mathrm{EC}$ using the pour thru extraction method. NC State University. Horticulture Information Leaflet 590, 2000.

[7] Thompson ML, Thompson EJ. Begonias: the complete reference. Times Books, New York, NY 1981.

[8] Whipker BE, Dasoju S, Dosmann MS, Iles JK. Effect of fertilizer concentration on growth of double impatiens. Hort Technol 1999; 9(3): 425-8.

[9] Chase AR, Poole RT. Effect of fertilizer rate on growth of fibrousrooted begonia. Hortscience 1987; 22 (1):162.

[10] Joiner JN, Smith TC. Some effects of nitrogen and potassium levels on flowering characteristics of Chrysanthemum morifolium, 'Bluechip'. Florida State Horticulture Society 1960; pp. 354-8.

[11] Bishko AJ, Fisher PR. Quantifying the $\mathrm{pH}$-response of a peat-based medium to application of basic chemicals. Hort Sci 2002; 37(3): 511-5.

[12] Haynes RJ. Leaching losses of nutrients and yield and nutrient uptake by container-grown begonia as affected by lime and fertiliser applications to a peat medium. J Sci Food Agric 1982; 33: 407-13.

[13] Wiedenfeld RP, Cox EL. Effects of limestone and irrigation level on salt levels and $\mathrm{pH}$ in potting media. Hort Sci 1988; 23(5): 844-5.

[14] Handreck K, Black N. Growing media for ornamental plants and turf. 3rd ed. UNSW Press, Sydney Australia 2002.

[15] Snowden RED, Wheeler BD. Iron toxicity to fen plant species. J Ecol 1993; 81(1): 35-46.

[16] Argo WR, Fisher PR. Understanding $\mathrm{pH}$ management for container-grown crops. Meister Publication 2003.

[17] Yoshiaki I. Nutrient deficiencies of crops. Food \& Fertilizer Technology Center, Taipei, Taiwan 1978. 